\title{
CONTRIBUTION OF THE ADDITIVE GENETIC EFFECTS IN SOYBEAN BREEDING AIMING AT THE AGRONOMIC IDEOTYPE
}

Maurício Horbach Barbosa ${ }^{1}$, (D) Ivan Ricardo Carvalho ${ }^{2 *}$, (D) José Antonio Gonzalez da Silva ${ }^{2}$, (D) Deivid Araújo Magano ${ }^{2}$, (D) Velci Queiróz de Souza ${ }^{3}$, Vinícius Jardel Szareski ${ }^{4}$, (D) Francine Lautenchleger ${ }^{5}$, (D) Danieli Jacoboski Hutra $^{2}$, (D) Natã Balssan Moura ${ }^{2}$, (D) Murilo Vieira Loro

1 Tropical Melhoramento e Genética, Rondonópolis, MT, Brazil;

2 Universidade Regional do Noroeste do Estado do Rio Grande do Sul, Ijui, RS, Brazil;

3 Universidade Federal do Pampa, São Gabriel, RS, Brazil;

4 SLC Agrícola, Correntina BA, Brazil;

5 Universidade do Centro-Oeste (Unicentro), Guarapuava, PR, Brazil.

* Corresponding author: Ivan Ricardo Carvalho (carvalho.irc@gmail.com).

Abstract: The development of new genotypes and their availability to the agricultural market is decisive for the success of the Brazilian soybean production chain. This study aimed to estimate the components of variance and genetic parameters of aspects of agronomic importance and to predict the selection of transgressive soybean populations and families based on the agronomic ideotype. The segregating families were conducted in an enlarged block design, composed of $285 \mathrm{~F}_{3}$ segregating families corresponding to the unusual treatments, and together with seven commercial cultivars assigned as common treatments, arranged in four replications. The characters of agronomic interest were measured the first pod insertion height, plant height, number of pods on the main stem, number of pods on the branches, pods containing only one seed, pods containing two seeds, pods containing three seeds, pods containing four seeds and seed mass. Were estimated additive genetic variance, genetic variance of the $F_{3}$ segregating families, genetic variance of $F_{2}$ segregating population, residual variance, phenotypic variance, narrow sense heritability, coefficient of determination for the effects of the $\mathrm{F}_{3}$ segregating family, coefficient of determination for the effects of the progeny, genetic variation coefficient, residual variation coefficient and predicted genetic ranking for the best $\mathrm{F}_{2}$ segregating populations and $\mathrm{F}_{3}$ segregating families. The pronounced additive genetic gains in the progeny showed higher values for the characters measured: first pod insertion height with $1.84 \%$, for the family and population, the additivity presented the highest values for the number of pods with four grains. The selection of the progenies through the agronomic ideotype based on the greatest genetic gains of the morphological characters weighted by the largest seed mass will thus lead these populations to joint selection for the other yield components.

Keywords: Genetic aspects for selection, initial generations of breeding, new genotypes 


\section{Introduction}

Originating from the Asian continent, the introduction of soybean in the Americas took place in the United States of America, where the first references in the statistical records of agriculture date back to 1924 (Berlan et al., 1977), the crop quickly showed rise and a century later the USA and Brazil have become the world's largest soybean producer in the world, surpassing 116 million tons of grain (Conab, 2019). This productive level is determined by the expansion of productive areas in Brazil, ranging from tropical and subtropical conditions culminating in the adjustment of the best genotype combined with efficient management.

The development of new genotypes and their availability to the agricultural market is decisive for the success of the Brazilian soybean production chain, in view of this, the breeding aims to develop cultivars that meet real or potential needs in a continuous and uninterrupted manner, this becomes possible through the understanding of the genetic variability and the processes of plant conduction that make it possible to identify individuals that meet the researcher's objectives and are effective in the agricultural sphere (Carvalho et al., 2017). There are aspects that are linked to the increase of the genetic variability of a breeding program, such as, the efficiency in forming segregating populations with high magnitude of individuals and high additive genetic contribution, search for genes and alleles in gene pools accessible through comercial cultivars, elite lines or the introduction of exotic germplasm, but great efforts must be directed to the maximization of gene and allele recombination through targeted crossings where complementarity between parents is decisive to obtain additive genetic effects (Pandini et al., 1997).

When understanding and obtaining segregating populations with high genetic potential, it is crucial to target selection strategies (Sediyama et al., 2005) towards segregating families that show the best expressions of agronomic characters and that meet the agronomic ideotype preferable by the current agricultural scenario, that is, cultivars with high grain yield, stable, adapted and responsive to the improvement of the environment, together with less use of water and nutritional resources to obtain the maximum physiological and metabolic responses that a plant requires throughout its cycle.

Due to the difficulty of obtaining the true genetic value of the segregating progenies, the use of statistical and biometric procedures that estimate and predict the magnitudes and the tendency of the genetic parameters extracted from the characters of interest that will assist the breeder during the breeding program is sought. In view of the lack of additive genetic information obtained in $F_{2}$ segregating populations and $F_{3}$ segregating families of soybeans, this study aimed to estimate the components of variance and genetic parameters of aspects of agronomic importance and to predict the selection of transgressive soybean populations and families based on the agronomic ideotype.

\section{Material and methods}

This work is linked to the IRC Soybean Breeding Program located in Campos Borges, Rio Grande do Sul, under the geographical coordinates: 28 $8^{\circ} 3^{\prime} 10^{\prime \prime}$ South and 52 $59^{\prime} 55^{\prime \prime}$ West, with an altitude of 513 meters. Artificial hybridizations were performed in the 2015/2016 crop season, the $F_{1 s}$ were conducted in 2016/2017, the $F_{2 s}$ were implanted in 2017/2018 and the $F_{3}$ segregating families were sown in the first half of November 2018 and harvested in March 2019, genealogical definitions are expressed in Table 1 in supplementary documents.

The segregating families were conducted in an enlarged block design (Peternelli et al., 2009), composed of $285 \mathrm{~F}_{3}$ segregating families corresponding to the unusual treatments, and together with seven commercial cultivars assigned as common treatments, arranged in four replications. All treatments were carried out in a direct seeding system, with NPK base fertilization in formulation 05-20-20, the experimental units contained two sowing lines five meters long, spaced by 0.5 meters, the standard population density was 250 thousand plants per hectare. The management of weeds, insect pests and diseases were carried out according to the need for the crop, aiming to minimize the external effects on the result of the experiment. 
Table 1. Variance component and genetic parameters for the characters first pod insertion, seed mass per plant, number of pods with one, two, three and four seeds, number of pods on the main stem, number of branches, plant height of 428 families from 35 soybean populations conducted in Campos Borges in the 2016/17 crop season.

\begin{tabular}{|c|c|c|c|c|c|c|c|c|c|c|}
\hline \multirow{2}{*}{ Parameter } & \multicolumn{10}{|c|}{ Characters } \\
\hline & FPI* & $\mathrm{PH}^{*}$ & NP1* & NP2* & NP3* & NP4* & NPMS* & NB* & NPB* & SM* \\
\hline$\sigma_{a}^{2}$ & 0.933 & 5.323 & 0.102 & 3.131 & 2.069 & 0.0005 & 0.652 & 0.042 & 4.123 & 1.109 \\
\hline$\sigma_{\text {fam }}^{2}$ & 10.965 & 78.399 & 5.45 & 35.191 & 43.257 & 0.002 & 21.919 & 1.012 & 124.27 & 15.633 \\
\hline$\sigma_{\text {pop }}^{2}$ & 13.705 & 158.895 & 13.576 & 85.485 & 31.007 & 0.006 & 14.543 & 1.079 & 155.307 & 23.458 \\
\hline$\sigma_{\mathrm{e}}^{2}$ & 25.27 & 396.749 & 38.421 & 285.667 & 250.56 & 0.079 & 122.304 & 6.017 & 769.481 & 129.382 \\
\hline$\sigma_{p}^{2}$ & 50.874 & 639.367 & 57.554 & 409.475 & 326.895 & 0.088 & 159.419 & 8.152 & 1053.18 & 169.583 \\
\hline$h^{2}{ }_{a}$ & 0.018 & 0.008 & 0.001 & 0.007 & 0.006 & 0.006 & 0.004 & 0.005 & 0.003 & 0.006 \\
\hline c2 $2_{\text {parc }}$ & 0.215 & 0.122 & 0.094 & 0.085 & 0.132 & 0.023 & 0.137 & 0.124 & 0.118 & 0.092 \\
\hline c2 $2_{\text {proc }}$ & 0.269 & 0.248 & 0.235 & 0.208 & 0.094 & 0.074 & 0.091 & 0.132 & 0.147 & 0.138 \\
\hline $\mathrm{CV}_{\mathrm{gi}} \%$ & 7.967 & 3.409 & 3.105 & 5.57 & 6.025 & 41.361 & 2.622 & 4.985 & 5.205 & 5.26 \\
\hline $\mathrm{CV}_{\mathrm{e}} \%$ & 36.306 & 21.445 & 41.527 & 35.945 & 47.159 & 293.746 & 25.706 & 41.956 & 50.02 & 38.282 \\
\hline General mean & 12.128 & 67.676 & 10.29 & 31.769 & 23.875 & 0.057 & 30.8 & 4.141 & 39.01 & 20.023 \\
\hline
\end{tabular}

\begin{tabular}{|c|c|c|c|c|c|c|c|c|c|c|}
\hline \multirow{2}{*}{ Parameter } & \multicolumn{10}{|c|}{ Characters } \\
\hline & FPI & $\mathrm{PH}$ & NP1 & NP2 & NP3 & NP4 & NPMS & NB & NPB & SM \\
\hline$\sigma^{2} a / \sigma^{2} p$ & 1.84 & 0.83 & 0.18 & 0.76 & 0.63 & 0.64 & 0.41 & 0.52 & 0.39 & 0.65 \\
\hline$\sigma^{2} a / \sigma^{2}$ fam & 8.52 & 6.79 & 1.87 & 8.90 & 4.78 & 27.36 & 2.98 & 4.21 & 3.32 & 7.10 \\
\hline$\sigma^{2} \mathbf{a} / \sigma^{2}$ pop & 6.81 & 3.35 & 0.75 & 3.66 & 6.68 & 8.52 & 4.49 & 3.95 & 2.66 & 4.73 \\
\hline$\sigma^{2} p a r c / \sigma^{2} p$ & 0.22 & 0.12 & 0.09 & 0.09 & 0.13 & 0.02 & 0.14 & 0.12 & 0.12 & 0.09 \\
\hline$\sigma^{2}$ proc $/ \sigma^{2} p$ & 0.53 & 0.04 & 0.41 & 0.05 & 0.03 & 84.80 & 0.06 & 1.62 & 0.01 & 0.08 \\
\hline$C V(\%) / C V_{r e}$ & 21.95 & 15.90 & 7.48 & 15.50 & 12.78 & 14.08 & 10.20 & 11.88 & 10.41 & 13.74 \\
\hline
\end{tabular}

The characters of agronomic interest were measured in the useful area of each experimental unit, for this purpose 10 representative random plants were collected, using the measurements of the first pod insertion height (FPI, cm), plant height $(\mathrm{PH}, \mathrm{cm})$, number of pods on the main stem (NPMS, units), number of pods on the branches (NPB, units), number of pods containing only one seed (NP1, units), number of pods containing two seeds (NP2, units), number of pods containing three seeds (NP3, units), number of pods containing four seeds (NP4, units) and seed mass (SM, g).

The data obtained were submitted to the assumptions of the statistical model, being normality, homogeneity and additivity, later, the model $y=X r+Z a+W p+T s+e$, was used, where: $y$ corresponds to the character of agronomic importance, $r$ represents the fixed effects of the repetitions attributed to the common treatments in each block, $a$ represents the additive genetic effects attributed as random, $p$ represents the random effects of the $\mathrm{F}_{2}$ segregating populations, $e$ shows the random effects obtained by the residues. The X, Z, W, T incidence matrices allow the orthogonality of the effects of this experiment. The characters of agronomic interest were subjected to the analysis of the likelihood-ratio test (LRT) through Deviance with significance based on the $\chi^{2}$ test at 0.05 probability.

After the significance of the models, the variance components and genetic parameters were estimated using the Restricted maximum likelihood (REML) method, obtaining the additive genetic variance $\left(\sigma^{2} a\right)$, genetic variance of the $F_{3}$ segregating families $\left(\sigma^{2}\right.$ fam $)$, genetic variance of $F_{2}$ segregating population $\left(\sigma^{2}\right.$ pop), residual variance $\left(\sigma^{2} \mathrm{e}\right)$, phenotypic variance $\left(\sigma^{2} p\right)$, narrow sense heritability $\left(h^{2} a\right)$, coefficient of determination for the effects of the $\mathrm{F}_{3}$ segregating family ( $\mathrm{c}^{2}$ parc), coefficient of 
determination for the effects of the progeny $\left(\mathrm{c}^{2}{ }_{\text {proc }}\right)$, genetic variation coefficient $\left(\mathrm{CV}_{\mathrm{gi}} \%\right)$, residual variation coefficient $\left(\mathrm{CV}_{\mathrm{e}} \%\right)$ and general average. With the estimates, predictions were obtained through the best linear unbiased prediction (BLUP), obtaining the predicted genetic ranking for the best $F_{2}$ segregating populations and $\mathrm{F}_{3}$ segregating families.

\section{Results and discussion}

The characters first pod insertion height, plant height, number of pods with one, two, three and four seeds, number of pods on the main stem and branches, number of branches and seed mass per plant revealed significance through the analysis of Deviance at $5 \%$ probability by the chi-square test. This indicates that the model chosen to represent the biological phenomenon is adequate and made it possible to estimate and predict reliable and consistent additive genetic trends. The dismemberments and proportionnalities obtained by understanding the components of variance make it possible to infer in detail what are the additive genetic contributions in the attributes of agronomic interest in soybean (Table 1), as well as to visualize the peculiarities of each segregating generation.

The phenotypic manifestation $\left(\sigma^{2} p\right)$ of a character is crucial for the breeder to make a careful selection in the breeding program. In this context, the additive genetic contribution $\left(\sigma^{2} a\right)$ in the phenotypic expression was estimated, defining that the first pod insertion height is the character with the highest contribution of additive gene actions with $1.8 \%$ of effects on the phenotype, the other characters studied revealed effects below $1 \%$.

The additive genetic contribution $\left(\sigma^{2} a\right)$ obtained in the segregating populations $F_{2}$ ( $\sigma^{2}$ pop) was vital for obtaining genetic gains for the soybean breeding aimed at the agronomic ideotype, in these conditions superiority of these effects were obtained for the character number of pods with four seeds, being this potentiated in $8.3 \%$ due to the additive gene actions, listing that genetic gains can already be obtained in $F_{2}$ for this character. With the understanding of the magnitude of additive genetic effects $\left(\sigma^{2} a\right)$ it was possible to understand that the $\mathrm{F}_{3}$ segregating families are highly influenced with $25.0 \%$ of additive genetic effects for the number of pods with four seeds, followed by $8.9 \%$ for pods with two seeds and $8.5 \%$ for the first pod insertion height. This superiority of the $F_{3}$ generation for the additive genetic contribution is due to the selection practices aimed at the maximum gain through genes and favorable alleles for phenotypic expression, in contrast, less additive genetic effects were seen in the $\mathrm{F}_{2}$ generation due to the large proportion of deviations from dominance, intragenic and intergenic actions common in this population generation.

When contrasting the genetic contributions of each generation $\left(\mathrm{F}_{2}\right.$ and $\left.\mathrm{F}_{3}\right)$ in the phenotypic expression, it is identified that the intrinsic genetic constitutions of the $F_{2}$ segregating populations enhance the characters first pod insertion height, plant height, number of pods with one, two and four seeds, number of branches and pods in the branches, as well as the seed mass per plant. The genetic effects of the $\mathrm{F}_{3}$ generation are superior in view of the number of pods with three seeds and the number of pods on the main stem of soybeans. The narrow sense heritability parameter represents the fraction really inheritable from a characteristic, being obtained by the ratio between the additive genetic variation and the total phenotypic fraction expressed for the character in question.

Therefore, maximizing this character means obtaining significant gains in the selection and during the process of breeding the crop, but this task is not simple, as there are many events and effects that minimize the magnitude of the parameter, for this the breeder should not only consider this parameter isolated but interpret it together with the specific variance components the nature of the genetic-statistical design.

The characters of agronomic interest showed relatively low magnitudes due to the fact that the $\mathrm{F}_{3}$ segregating generation still reveals $25 \%$ of its genetic constitution composed of heterozygotes, while the generations advance, the parameter tends to be increased, in decreasing order of magnitude there is superiority for the first pod insertion height, plant height, number of pods with two, three and four seeds, seed mass per plant, number of branches, pods on the stem and branches and number of pods with only one seed. 
The determination coefficients obtained are adequate for the effects of $F_{2}$ segregating populations ( $c^{2}$ parc) and $F_{3}$ families ( $c^{2}$ proc), which are essential for the reliability of the estimates of the parameters obtained. The ratio between the coefficients of genetic and residual variation indicates the conditions to carry out selection for the character of interest, in these conditions it is identified that high total genetic variability was presented for the first pod insertion height, plant height, number of pods with two seeds and seed mass per plant. This fact indicates the greater probability of identifying and selecting a transgressive gene constitution for these characters.

The selection based on the best linear unbiased prediction (BLUP) shows the ranking of the upper $F_{2}$ populations and the $F_{3}$ segregating family, establishing which gene constitutions are more likely to generate superior or suitable progenies for the agronomic ideotype.

The first pod insertion height is based on the ideotype of a plant that contemplates magnitudes from 10 to 15 centimeters in relation to the ground level, being beneficial for mechanized harvesting practices in growing environments with rugged relief, as well as allowing the maximization of the plant's production zone with superior expansion of total and reproductive nodes (Silva et al., 2010; Almeida et al., 2011).

Based on the breeding ideal for this characteristic, the genetic potential to be explored in the $\mathrm{F}_{2}$ generation is directed to the crossings MG1xPG27, MG25xPG6, MG1xPG2, MG29xPG28 and MG1xPG3. The selection based on the F3 family level with regard to the ideotype was directed at families 7, 2, 4, 10, 9, $14,13,8,5,12$ these being of high genetic value and all of them originating from the IRC 001 population obtained by crossing the MG1xMG2 parents. In this context, the selection for this character must be cautious since the effects obtained at the population level do not last widely in subsequent generations.

The plant height character contemplates a general average of $67 \mathrm{~cm}$. This refers to the new conformation of the soybean breeding ideotype, since a small size seeks the best use of photosynthetically active radiation, partition of assimilates and maximum efficiency of the leaf area within an optimum arrangement of plants in the crop, old cultivars were selected for ranges between 90 to $100 \mathrm{~cm}$ (Reni and Rao, 2013), however currently soybean expresses capacity to exceed six tons in conditions of highly technified fields, where expensive expenses of assimilated or low productive efficiency (Corassa et al., 2018; Hammer et al., 2018). Weighted by the current excellent agronomic soybean, selection at the level of $\mathrm{F}_{2}$ populations should be directed to MG29xPG28, MG1xPG3, MG26xPG17 and MG7xPG5, by directing the selection to the $F_{3}$ segregating generation, the ideotype is met through families $2,5,9,7,14,12,6,4,10$ and 11 these come from the IRC 001 population obtained by crossing the MG1xMG2 parents, which presented a height slightly above the ideal, but these effects will be minimized when advancing for generations where genes predominate in homozygous conformations, whereas non-additive dominance deviations are balanced, phenotypic manifestations are adequate for the purpose of selection.

The distribution of the total pods for the different amounts of seeds per pod was two seeds (48.1\%), three seeds $(36.2 \%)$, one seed (15.6) and four seeds $(<1 \%)$. Thirteen populations showed a genetic contribution to increase the character of pods with one seed. Twelve populations showed a genetic contribution to increase the character of pods with two seeds. Fifteen populations showed a genetic contribution to increase the character of pods with three seeds. Nine populations showed a genetic contribution to increase the character of pods with four seeds.

The contribution of the genetic component is evident in determining the selection for the concentration of certain constitutions for the number of pods per plant. As previously discussed, the contribution of genetic variance represented more than $60 \%$ of the explanation of the phenotypic variation for three of the four characters of number of seeds per pod (NP2: 76\%, NP3: $63 \%$ and NP4: $64 \%$ ). The stability regarding the production of different sizes of pods had already been reported in the literature, attributing the intrinsic improvements of the 
environment to the increase of pods per plant than seeds per pod (Liu et al., 2010). In this way the contribution of the environment is reduced, leaving the expression of the characteristic from the genetic contribution.

For the selection of families, those that composed the highest magnitudes for the genetic contribution were highlighted, thus presenting the highest predicted phenotypic averages. The selection for number of pods with one seed stood out in families $3,1,2,4,6,5,16,13,12$ and 8 . For pods with two seeds, families $8,3,1,7,6,5$, 2, 4, 16 and 9 stood out. For pods with three seeds, the highest magnitudes were for families $6,8,3,7,1,5,2,4,14$ and 16 . The selection of the best families for the character pods with four seeds was carried out for families 1, 7, 6, 2, 3, 5, $4,8,13$ and 16. Similarity in family behavior is noted, so that families $1,2,3,4,5,6,8$ and 16 stand out as the highlight for the four morphological variables of the pod, coming from the crossing MG1 x MG2 and MG3 x MG2. The familiarity of the number of pods per plant with the crop yield can be explored for such, since its new phenotypic mean predicted surpasses the other families.

The intensification of technical growing management makes it possible to increase the number of pods formed per plant (Liu et al., 2010). Thus, the selection of families with more than two pods becomes relevant, considering the possibility of having genotypes that have a high capacity for seed formation per plant, given problems arising from management, mainly in terms of chemical fertilization and water availability, are apparently surpassed by a large part of farmers (Du et al., 2019; Lopez et al., 2019). In order to select populations, those that stand out for the largest number of pos on the main stem, come from the crosses MG26 $x$ PG17, MG23 x PG23, MG11 x PG3 and MG7 x PG5. Fourteen populations showed positive magnitudes for the character pods on the main stem. Families 6, 3, 1, 2, 4, 5, 9, 14, 8 and 7 were selected according to the new predicted phenotypic mean, from the crossing of MG1 $x$ MG2.

Branches promote the best use of the space available in the cultivation canopy. The lateral development of the plant, associated with the increase of photosynthetically active leaf area, promotes the increase of meristematic regions, which may differ in reproductive structures (Pelegrin et al., 2017). Zanon et al. (2015) report the contribution of up to $31 \%$ for specific cultivars and close to $20 \%$ for cultivars with an indeterminate growth habit. The number of branches per plant is widely distributed, from 1.8 to 7 (Barbosa, et al., 2014; Szareski et al., 2015), reaching 8 through the use of plant regulators (Campos et al., 2009). Twelve populations showed positive genetic value, which, likewise, stand out as a highlight for the new predicted phenotypic mean, of which the crosses MG2 $\mathrm{x}$ PG13, MG20 x MG20, MG26 x PG21, MG24 X PG24, MG27 x MG23. The average was higher than four branches per plant, reaching magnitudes higher than seven, within what has already been reported in the literature. The behavior of the phenotypic mean owed to the families remained just as described at the population level, such that the best $\mathrm{F}_{3}$ families 6 , $5,3,1,4,2,8,7,14$ and 18, in which they come from crosses MG1 x PG2 and MG3 x PG2.

For the number of pods in the branches, twelve populations stood out in terms of genetic value, in which the crosses MG20 x PG20, MG26 x PG21, MG21 x MG21, MG3 x PG6, MG2 x PG13, MG23 x PG23, MG7 x PG8 stood out. At the family level, the best predicted averages were evidenced by $3,8,6,1,7,5,4,2$, 16 and 17. The families that stood out the most came from the crossing MG1 x PG2. Even if the association between the characters number of branches and number of pods in the branches is positive, both should be considered together, in fact, we seek to increase the number of pods in the branches and also the number of branches. However, the reverse must be taken care of, since the excessive increase in ramifications has repercussions on the expenditure of photoassimilates that could have been redirected to the formation or increase in the density of seeds (Nardino et al., 2017). Grain yield is the character that the independent soybean breeding program guides research, since neither does a cultivar stand out for its exclusive character, if it is not attractive in the eyes of the grower, nor does it meet the demand of the consumer market, it will not remain for long periods in the catalog of elite cultivars. The product of the final process 
of crop development, in this way, all the periods of growth and development of the crop that precede it exert influence on the magnitude and expression of this character.

Estimates and forecasts suggest that the demand in 2050 exceeds twice the current demand for oilseeds (Ray et al., 2013). Still according to the same authors, the rate of annual yield increase will not be sufficient. The selection based on genetic values, as well as the prediction of the new predicted mean appear as the alternative for the selection of genotypes that support the market demand.

Fourteen populations exceeded the average for the seed mass character per plant, in which the crosses MG2 x PG13, MG26 x PG17, MG11 x PG3, MG23 x PG23, MG21 x PG21 stood out. For the selection in $\mathrm{F}_{3}$, families $6,3,1,2,4,5,8$, 13,16 and 14 stood out, the ones that stood out most came from the parents MG1 x PG2. When population selection is used, it can mask the best families, as it is based on the population average, it can be misleading, where a population is selected that, over the generations, will not present the desired characteristics. When using the genealogical method, it allows more assertive results in the selection of families in the field.

\section{Conclusion}

The pronounced additive genetic gains in the progeny showed higher values for the characters measured: first pod insertion height with $1.84 \%$, for the family and population, the additivity presented the highest values for the number of pods with four grains. The selection of the progenies through the agronomic ideotype based on the greatest genetic gains of the morphological characters weighted by the largest seed mass will thus lead these populations to joint selection for the other yield components.

\section{References}

BARBOSA, G.F.; CRUZ CENTURION, M.A.P.; FERRAUDO, A.S. 2014. Potencial do manejo integrado da ferrugem asiática da soja: severidade da doença, desenvolvimento vegetativo e componentes da produção, cultivar MG. Bioscience Journal. 30(3).

BERLAN, J.P.; BERTRAND, J.P.; LEBAS, L. 1977. The growth of the American "soybean complex". European Review Agricultural. 4(4): 395-416.

CAMPOS, M.F.; ONO, E.O.; RODRIGUES, J.D. 2015. Desenvolvimento da parte aérea de plantas de soja em função de reguladores vegetais. Ceres. 56(1).

CARVALHO, I.R.; NARDINO, M.; SOUZA, V.Q. 2017. Melhoramento e Cultivo da Soja. Editora Cidadela. Ed.1 Porto Alegre.

CONAB. (2019). Análise mensal, Soja. Available at: <https://www.conab.gov.br/infoagro/analises-do-mercado-agropecuario-e-extrativista/analises-do-mercado/historico-mensalde-soja $>$

CORASSA, G.M.; SANTI, A.L.; AMADO, T.J.C.; REIMCHE, G.B.; GAVIRAGHI, R.; BISOGNIN, M.B.; PIRES, J.L.F. 2018. Performance of soybean varieties differs according to yield class: a case study from Southern Brazil. Precision Agriculture. 1-21.

COSTA, M.M.; DI MAURO, A.O.; UNÊDA-TREVISOLI, S.H.; ARRIEL, N.H.C.; BÁRBARO, I.M.; MUNIZ, F.R.S. 2004. Ganho genético por diferentes critérios de seleção em populações segregantes de soja. Pesquisa Agropecuária Brasileira. 39(11): 1095-1102.

CRUZ, C.D. 2001. Programa Genes: aplicativo computacional em genética e estatística. UFV. 
DE ALMEIDA, R.D.; PELUZIO, J.M.; AFFÉRRI, F.S. 2011. Divergência genética entre cultivares de soja, sob condições de várzea irrigada, no sul do Estado Tocantins. Revista Ciência Agronômica. 42(1): 108-115.

DU, Y.; ZHAO, Q.; LI, S.; YAO, X.; XIE, F.; ZHAO, M. 2019. Shoot/root interactions affect soybean photosynthetic traits and yield formation: a case study of grafting with record-yield cultivars. Frontiers of Plant Science. 10(1) 108-116.

HAMMER, D.J.; STOLTENBERG, D.E.; COLQUHOUN, J.B.; CONLEY, S.P. 2018. Has Breeding Improved Soybean Competitiveness with Weeds. Weed science, 66(1): 57-61.

LAZARINI, E. 1995. Avaliação das características agronômicas e análises nutricionais de genótipos de soja semeados em diferentes épocas, em Jaboticabal-SP. 1995. Tese de Doutorado. Faculdade de Ciências Agrárias e Veterinárias da Universidade Estadual Paulista.

LIU, B.; LIU, X.B.; WANG, C.; LI, Y.S.; JIN, J.; HERBERT, S.J. 2010. Soybean yield and yield component distribution across the main axis in response to light enrichment and shading under different densities. Plant Soil Environment. 56(8): 384-392.

LOPEZ, M.A.; XAVIER, A.; RAINEY, K.M. 2019. Phenotypic Variation and Genetic Architecture for Photosynthesis and Water Use Efficiency in Soybean (Glycine max L. Merr) Frontiers of Plant Science. 10: 680.

MATEI, G.; BENIN, G.; WOYANN, L.G.; DALLÓ, S.C.; MILIOLI, A.S.; ZDZIARSKI, A.D. 2017. Agronomic performance of modern soybean cultivars in multi-environment trials. Pesquisa Agropecuária Brasileira. 52(7): 500-511.

NARDINO, M.; SOUZA, V.Q.; BUSANELLO, C.; BAHRY, C.A.; CARON, B.O.; ZIMMER, P.D.; SCHIMIDT, D. 2015. Desfolha artificial em estádios vegetativos e suas implicações a cultura da soja. Magistra. 27(2): 199-207.

PANDINI, F.; CARVALHO, F.I.F.; BARBOSA NETO, J.F. 1997. Avaliação da variabilidade genética em triticale para ciclo e estatura de planta obtida a partir de mutações induzidas e cruzamentos artificiais. Pesquisa Agropecuária Gaúcha 3: 55-61.

PELEGRIN, A.J.; CARVALHO, I.R.; SOUZA, V.Q. 2017. Ideótipo agronômico para caracteres morfológicos, componentes de rendimento e bromatológicos da soja, In Carvalho, I. R., Nardino, M., Souza, V. Q. Melhoramento e Cultivo da Soja. Editora Cidadela. Ed.1 Porto Alegre.

PETERNELLI, L.A.; SOUZA, E.F.M.D.; BARBOSA, M.H.P.; CARVALHO, M.P.D. 2009. Delineamentos aumentados no melhoramento de plantas em condições de restrições de recursos. Ciência Rural. 39(9): 2425-2430.

RAY, D.K.; MUELLER, N.D.; WEST, P.C.; FOLEY, J.A. 2013. Yield trends are insufficient to double global crop production by 2050. PloS one. 8(6): e66428.

RENI, Y.; PUSHPA, R.A.O.; KOTESWARA, Y. 2013. Genetic variability in soybean [Glycine max (L) Merrill]. International Journal of Plant, Animal and Environmental. 3(4): 35-38.

RESENDE, M.D.V. 2007. Selegen-Reml/Blup: sistema estatístico e seleção genética computadorizada via modelos lineares mistos. Colombo: Embrapa Florestas. 
SEDIYAMA, T.R.; TEIXEIRA, R.C.; REIS, M.S. 2005. Melhoramento da soja. In: Melhoramento de espécies cultivadas. 2: 553-603.

SILVA, J.B.D.; LAZARINI, E.; SILVA, A.M.; RECO, P.C. 2010. Ensaio comparativo de cultivares de soja em época convencional em Selvíria, ms: características agronômicas e produtividade. Bioscience Journal. 747-754. 2010.

SPILKE, J.; PIEPHO, H.P.; HU, X. 2005. Analysis of unbalanced data by mixed linear models using the MIXED procedure of the SAS system. Journal Agronomy Crop Science. 191(1): 47-54.

SZARESKI, V.J.; SOUZA, V.Q.; CARVALHO, I.R.; NARDINO, M.; FOLLMANN, D.N.; DEMARI, G.H.; FERRARI, M.; OLIVOTO, T. 2015. Ambiente De Cultivo E Seus Efeitos Aos Caracteres Morfológicos E Bromatológicos Da Soja. Revista Brasileira de Agropecuária Sustentável. 5(2) 747-754.

ZANON, A.J.; STRECK, N.A.; RICHTER, G.L.; BECKER, C.C.; ROCHA, T.S.M.; CERA, J.C.; WINCK, J.E.M.; CARDOSO, A.P.; TAGLIAPIETRA, E.L.; WEBER, O.S. 2015. Contribuição das ramificações e a evolução do índice de área foliar em cultivares modernas de soja. Bragantia, 74(3): 279-290. 